\title{
Dye Anionic Removal From Water by Green Synthesized Nannochloropsis Sp.- Cetyltrimethylammonium Bromide Surfactant: Kinetics, Adsorption Isotherm and Adsorbent Regeneration
}

Buhani . ( $\square$ buhani_s@yahoo.co.id )

University Lampung https://orcid.org/0000-0003-2289-1804

Nurul Miftahza

Universitas Lampung

Suharso.

Universitas Lampung Fakultas Matematika dan Ilmu Pengetahuan Alam

Desy Permatasari

Universitas Lampung Fakultas Matematika dan Ilmu Pengetahuan Alam

Sumadi .

Universitas Lampung Fakultas Teknik

Keywords:

Posted Date: June 9th, 2021

DOI: https://doi.org/10.21203/rs.3.rs-585279/v1

License: (c) (i) This work is licensed under a Creative Commons Attribution 4.0 International License. Read Full License 


\section{Abstract}

The authors have requested that this preprint be removed from Research Square. 